\title{
PENGARUH PENGGUNAAN MINYAK KELAPA DALAM RANSUM TERHADAP BOBOT BADAN AKHIR, BOBOT DAN PERSENTASE KARKAS, SERTA PERSENTASE LEMAK ABDOMINAL PADA AYAM BURAS SUPER
}

\author{
Yosua Nelwan, Jein R. Leke*, Florencia N. Sompie, Jacqueline T. Laihad
}

Fakultas Peternakan Universitas Sam Ratulangi, 95115

\begin{abstract}
ABSTRAK
Penelitian ini bertujuan untuk mengetahui sejauh mana penggunaan minyak kelapa terhadap bobot badan akhir, bobot karkas, persentase karkas, dan persentase lemak abdominal pada ayam buras super. Materi penelitian yang digunakan adalah 100 ekor unsexed berumur 8 minggu rataan berat awal 862,24 $\mathrm{g}$ dengan standart deviasi 44,13 g. Perlakuan diberikan $\mathrm{R} 0$ : ransum basal tanpa minyak kelapa (mk); R1 : ransum basal 99,5\% + 0,5\% mk; R2 : ransum basal $99 \%+1 \% \mathrm{mk} ; \mathrm{R} 3$ : ransum basal $98,5 \%+$ $1,5 \% \mathrm{mk} ; \mathrm{R} 4$ : ransum basal $98 \%+2 \% \mathrm{mk}$. Rancangan acak lengkap (RAL) dengan 5 perlakuan dan 5 ulangan dengan masingmasing perlakuan diisi dengan 4 ekor ayam buras super total 100 ekor ayam, uji lanjut bnj. Variebel yang diukur dalam penelitian bobot badan akhir, bobot dan persentase karkas serta persentase lemak abdominal. Hasil penelitian ini memberikan respons yang sama terhadap persentase karkas dan lemak abdominal, tetapi memberikan pengaruh berbeda nyata terhadap bobot badan akhir dan bobot karkas. Disimpulkan bahwa Penggunaan minyak kelapa sampai $2 \%$ dalam ransum ayam buras super dapat meningkatkan bobot bad an akhir, dan bobot karkas tetapi menghasilkan persentase karkas dan persentase lemak abdominal yang sama.
\end{abstract}

Kosepondensi (corresponding author)

Email: rinileke@unsrat.ac.id
Kata kunci: Ayam buras super, minyak kelapa.

\section{ABSTRACT}

UTILIZATION EFFECT OF COCONUT OIL IN RATION ON BODY WEIGHT, PERCENTAGES OF CARCASS AND ABDOMINAL FAT IN SUPER NA TIVE HENS. This study was conducted to evaluate utilization effect of coconut oil in ration on body weight, percentages of carcass and abdominal fat in super native hens. This study was involving hundred unsexed super native hens at ages of eight weeks with the average initial body weight of $862.24 \mathrm{~g} \pm 44.13 \mathrm{~g}$. The treatments were ration without coconut oil (CO) utilization (R0), ration of $99.5 \%$ basal added with $0.5 \% \mathrm{CO}(\mathrm{R} 1)$, ration of $99 \%$ basal added with $1 \% \mathrm{CO}(\mathrm{R} 2)$, ration of $98.5 \%$ basal added with $1.5 \% \mathrm{CO}(\mathrm{R} 3)$, and ration of $98.0 \%$ basal added with $2.0 \% \mathrm{CO}$ (R4). The completely randomized design was applied as design with five treatments consisted of five replications at each treatment. Each experimental unit was put four heads of super native hens. The significant treatments were tested by Duncan's test. Variables measured were life body weight, slaughter body weight, carcass weight and carcass percentage as well as abdominal percentage. Results showed that utilization effect of coconut oil in ration had the same effects on percentages carcassand abdominal fat, but had significant effect on life body weight and carcass weight. Therefore, it was concluded that utilizatilization of coconut 
oil up to 2 percents in ratio increased life body weight and carcass weight.

Keyword: carcass weight, coconut oil, super native chicken.

\section{PENDAHULUAN}

Ayam buras super terus menerus mengalami peningkatan-peningkatan yang pesat di Indonesia. Peternakan ayam buras super dalam mendukung ekonomi masyarakat pedesaan mempunyai peranan yang cukup besar, karena memiliki daya adaptasi yang tinggi terhadap lingkungan dan pemeliharaannya relatif lebih mudah serta tidak membutuhkan modal besar. Berdasarkan data dari Bad an Pusat Statistik Sulawesi Utara tahun 2018, populasi ayam buras selama 4 tahun terakhir terus meningkat yaitu di tahun 2015 berjumlah 2.342.204 ekor, 2016 berjumlah 2.375.058 ekor, 2017 berjumlah 2.406 .022 ekor, dan di tahun 2018 mencapai 2.448 .771 ekor.

Usaha memenuhi permintaan ayam buras terhadap masyarakat yang terus meningkat, maka perlu peningkatan produktivitas ayam buras. Ayam buras super hasil persilangan ayam ras petelur betina dengan ayam kampung penjantan yang mempunyai postur besar. Ayam buras super memiliki pertumbuhan lebih cepat dari pada ayam lokal. protein dan energi yang dibutuhkan ayam buras super sesuai umur. Fase starter 0-12 minggu protein 1517\% dan energi $2600 \mathrm{kkal}$, grower 12-22 minggu protein $14 \%$ dan energi $2400 \mathrm{kkal}$, dan layer $>22$ protein $14 \%$ serta energi 2400-2600 kkal.

Ayam buras super dapat bertumbuh lebih cepat apabila diberikan ransum yang sesuai dengan kebutuhan nutrisinya. Pemeliharaan ayam buras super fase grower bertujuan menghasilkan bobot badan dan karkas yang tinggi. Biaya ransum yang mencapai $70 \%$ merupakan faktor terbesar yang memengaruhi usaha peternakan ayam buras super. Kualitas ransum memengaruhi produktivitas ternak. Ransum dikatakan berkualitas bila komposisi nutrien dan keseimbangannya sesuai dengan kebutuhan ternak.

Keseimbangan nutriennya yang penting diperhatikan dalam menyusun ransum unggas, yaitu keseimbangan protein dan energi. Imbangan energi dan protein yang tidak sesuai kebutuhan ayam buras super sering menjadi permasalah peternak dalam upaya peningkatan produksi ayam buras super. Untuk itu tingkat energi dan protein yang tepat, perlu sangat penting diperhatikan dalam menyusun ransum.

Energi dalam tubuh ayam untuk memenuhi hidup pokok meliputi kebutuhan metabolis basal dan aktivitas normal. Peningkatan imbangan energi ransum mengakibatkan peningkatan sejumlah 
nutrien yang akhirnya menyebabkan meningkatkan bobot ayam dan efiensi penggunaan ransum. Minyak kelapa merupakan bahan sumber energi yang dapat digunakan untuk mencukupi kebutuhan energi ransum ayam buras super. Ransum dengan minyak kelapa yang sesuai kebutuhan ayam buras super dapat meningkatnya waktu retensi (Retention time) ransum dalam usus dan juga menyebabkan proses digesti dan absorsi konstituen non lemak akan lebih sempurna (Prayogi, 2007). Minyak kelapa yang dibuat dari buah kelapa 10 biji menghasilkan $1500 \mathrm{~g}$, minyak kelapa dapat digunakan sebagai sumber energi.

Sulawesi utara sering disebut dengan julukan daerah nyiur melambai, karena areal perkebunan kelapa yang sangat luas dan penghasil kelapa terbesar.

Berdasarkan data Pusat Statistik (Ditjenbun, 2017) areal perkebunan kelapa Sulawesi Utara seluas 275,656 hektar, produksi kelapa sebanyak 265,637 ton dan minyak kelapa mencapai 167,31 juta ton. Hasil analisa laboratorium Institut Pertanian Bogor tahun 2018 kandungan nutrien yang terdapat dalam minyak kelapa yaitu lemak 6,22 dan energi metabolis $6334,1 \mathrm{kkal} / \mathrm{kg}$.

Berdasarkan uraian-uraian tersebut diatas, maka tujuan penelitian yaitu pengaruh penggunaan minyak kelapa dalam ransum terhadap bobot badan akhir, bobot dan persentase karkas, serta persentase lemak abdominal pada ayam buras super.

\section{MATERI DAN METODE PENELITIAN}

Ternak yang digunakan yaitu ayam buras super sebanyak 100 ekor umur 2 bulan (unsexed) rataan berat awal 862,24g (standar deviasi 44,13). Dalam penelitian ini menggunakan kandang sistem baterai dengan ukuran berukuran $40 \mathrm{~cm}$ x $60 \mathrm{~cm} \mathrm{x}$ $35 \mathrm{~cm}$ sebanyak 25 unit. Susunan ransum penelitian terdiri dari jagung 56\%, dedak padi $17 \%$, tepung ikan $13 \%$, bungkil kelapa $13,5 \%$, top mix $0,5 \%$.

Level minyak kelapa yang diberikan pada masing-masing perlakuan yaitu:

$\mathrm{R}_{0}=$ Ransum basal $100 \%$ (tanpa minyak kelapa);

$\mathrm{R}_{1}=$ Ransum basal 99,5\% + minyak kelapa $0,5 \%$

$\mathrm{R}_{2}=$ Ransum basal $99 \%$ + minyak kelapa $1 \%$;

$\mathrm{R}_{3}=$ Ransum basal 98,5\% + minyak kelapa $1,5 \%$;

$\mathrm{R}_{4}=$ Ransum basal 98\% + minyak Kelapa $2 \%$.

Ransum yang digunakan dalam penelitian dan komposisi zat-zat nutrien dapat dilihat pada Tabel 1 dan Tabel 2. Proses pembuatan minyak kelapa dapat dilihat pada Gambar 1. 
Tabel 1. Komposisi Zat nutrien Bahan Pakan Penyusun Ransum

\begin{tabular}{lcccccccc}
\hline Bahan Makanan & $\begin{array}{c}\text { Protein } \\
\%\end{array}$ & $\begin{array}{c}\text { SK } \\
\%\end{array}$ & $\begin{array}{c}\text { Lemak } \\
\%\end{array}$ & $\begin{array}{c}\text { Ca } \\
\%\end{array}$ & $\begin{array}{c}\text { P } \\
\%\end{array}$ & $\begin{array}{c}\text { Lisin } \\
\%\end{array}$ & $\begin{array}{c}\text { Metonin } \\
\%\end{array}$ & $\begin{array}{c}\text { EM } \\
\mathrm{Kkal} / \mathrm{kg}\end{array}$ \\
\hline Tepung Jagung & 8,85 & 3,45 & 7,71 & 0,02 & 0,3 & 0,24 & 0,2 & 3300 \\
Tepung Ikan & 63 & 0,5 & 9,3 & 5,3 & 2,58 & 4,82 & 2,27 & 2960 \\
Bungkil Kelapa & 18,6 & 15,38 & 12,55 & 0,1 & 0,6 & 0,68 & 0,5 & 1400 \\
Dedak Halus & 12 & 16,83 & 6,58 & 0,2 & 1 & 0,57 & 0,22 & 2400 \\
Minyak Kelapa* & & & 6,22 & & & & & 6334,1 \\
Top Mix & & & & & & & & \\
\hline
\end{tabular}

Keterangan: Energi metabolis didapat $70 \% \times$ gross energi

Sumber: Leke, 2013

*Laboratorium Ilmu dan Teknologi Pakan (IPB) 2018

Tabel 2. Komposisi Ransum Basal

\begin{tabular}{lccccccccc}
\hline $\begin{array}{l}\text { Bahan } \\
\text { Makanan }\end{array}$ & Penggunaan & $\begin{array}{c}\text { Protein } \\
\%\end{array}$ & $\begin{array}{c}\text { SK } \\
\%\end{array}$ & $\begin{array}{c}\text { Lemak } \\
\%\end{array}$ & $\begin{array}{c}\text { Ca } \\
\%\end{array}$ & $\begin{array}{c}\text { P } \\
\%\end{array}$ & $\begin{array}{c}\text { Lys } \\
\%\end{array}$ & $\begin{array}{c}\text { Met } \\
\%\end{array}$ & $\begin{array}{l}\mathrm{EM} \\
\mathrm{Kkal} / \\
\mathrm{kg}\end{array}$ \\
\hline Jagung & 56 & 4,63 & 1,93 & 4,32 & 0,01 & 0,17 & 0,13 & 0,11 & 1848 \\
Tepung Ikan & 13 & 8,27 & 0,07 & 1,21 & 0,69 & 0,34 & 0,62 & 0,02 & 384,8 \\
Dedak & 17 & 2,04 & 2,81 & 1,12 & 0,03 & 0,48 & 0,09 & 0,06 & 408 \\
Bungkil K & 13,5 & 2,51 & 2,08 & 1,70 & 0,01 & 0,08 & 0,09 & 0,06 & 189 \\
Top Mix & 0,5 & & & & & & & & \\
\hline
\end{tabular}

Tabel 3. Komposisi Zat Nutrien dan Energi Metabolisme Ransum Perlakuan

\begin{tabular}{lccccc}
\hline Perlakuan & R0 & R1 & R2 & R3 & R4 \\
\hline Ransum basal & 100 & 99,5 & 99 & 98,5 & 98 \\
Minyak kelapa & 0 & 0,5 & 1 & 1,5 & 2 \\
\hline Zat makanan & & & & & \\
\hline Protein (\%) & 17,45 & 17,36 & 17,28 & 17,19 & 17,10 \\
Serat kasar $(\%)$ & 6,88 & 6,85 & 6,81 & 6,78 & 6,75 \\
Lemak (\%) & 8,34 & 8,33 & 8,32 & 8,31 & 8,30 \\
Ca $(\%)$ & 0,75 & 0,74 & 0,74 & 0,74 & 0,73 \\
P (\%) & 1,07 & 1,06 & 1,05 & 1,05 & 1,04 \\
Lisin(\%) & 0,95 & 0,94 & 0,94 & 0,93 & 0,93 \\
Metonin (\%) & 0,51 & 0,25 & 0,24 & 0,24 & 0,24 \\
EM (kkal/kg) & 2829,8 & 2847 & 2865 & 2882 & 2900 \\
\hline
\end{tabular}

Keterangan: Dihitung berdasarkan Tabel 1 dan Tabel 2. 


\section{Pembuatan Minyak Kelapa}

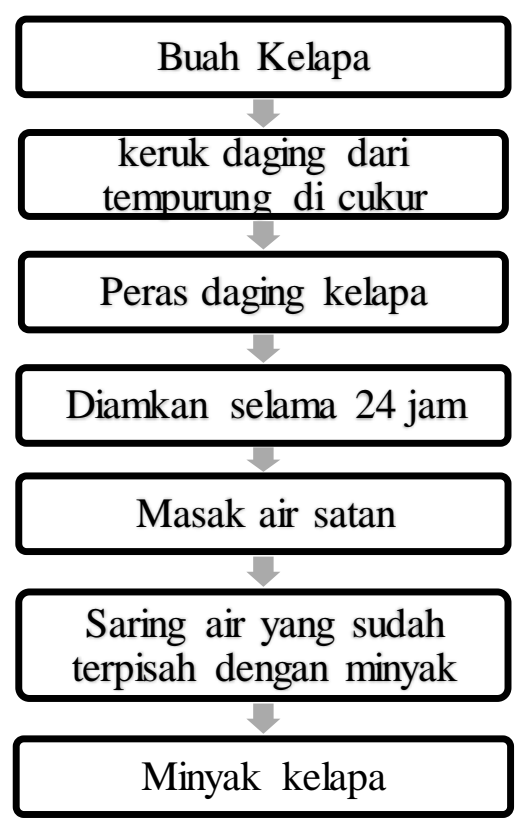

Gambar 1. Skema Pembuatan Minyak Kelapa

\section{Variabel yang diukur}

\section{Bobot badan akhir}

Bobot badan akhir g (bobot hidup) dihitung dengan cara penimbangan diakhir penelitian.

\section{Bobot karkas}

Bobot karkas (g/ekor) dihitung tanpa darah, bulu, kepala, kaki, leher, dan organ dalam.

\section{Persentase karkas}

Persentasi karkas $(\%)=$

$\frac{\text { Bobot karkas }}{\text { Bobot badan akhir }} \times 100 \%$

\section{Analisa Data}

Data penelitian ini dianalisa menggunakan program Microsoft excel 2007. Analisis keragaman rancangan acak lengkap dilanjutkan dengan uji BNJ jika terdapat perbedaan nyata (Steel and Torrie, 1995).

\section{HASIL DAN PEMBAHASAN}

\section{Pengaruh Perlakuan Terhadap Bobot Badan Akhir}

Berdasarkan data pada Tabel 4 dapat diketahui rataan bobot badan akhir ayam buras super yang dihasilkan penelitian diperoleh pada ayam buras yaitu umur 16 minggu. Rataan tertinggi pada 
Tabel 4. Rataan Bobot Badan Akhir, Bobot, Persentase Karkas, dan Persentase Lemak Abdominal.

\begin{tabular}{lllllc}
\hline \multirow{2}{*}{ Parameter } & \multicolumn{4}{c}{ PERLAKUAN } \\
\cline { 2 - 6 } & \multicolumn{1}{c}{$\mathrm{R} 0$} & $\mathrm{R} 1$ & $\mathrm{R} 2$ & $\mathrm{R} 3$ & $\mathrm{R} 4$ \\
\hline Bobot Badan Akhir $(\mathrm{g})$ & $12574^{\mathrm{a}}$ & $1513,8^{\mathrm{b}}$ & $1563,6^{\mathrm{b}}$ & $1786,6^{\mathrm{cd}}$ & $1782,2^{\text {cd }}$ \\
Bobot Karkas (g) & $884,8^{\mathrm{a}}$ & $928,4^{\mathrm{ab}}$ & $1092,4^{\mathrm{b}}$ & $1240,8^{\text {cd }}$ & $1200^{\mathrm{cd}}$ \\
Persentase Karkas $(\%)$ & 70,21 & 70,24 & 69,91 & 69,50 & 66,95 \\
Persentase Lemak Abdominal (\%) & 1,35 & 0,60 & 0,82 & 1,26 & 1,34 \\
\hline Keterangan : Superskrip yang berbeda pada baris yang sama menunjukan berbeda sangat nyata $(\mathrm{P}<0,01)$
\end{tabular}

perlakuan $\mathrm{R}_{3}(1786,6 \mathrm{~g})$ dan terendah berada pada perlakuan $\mathrm{R}_{0}(1257,4 \mathrm{~g})$. Sartika (2016) dalam penelitian bahwa pada umur 16 minggu ayam buras super berat berkisar 1,092 - 1,444 g. Berdasarkan uji keragaman perlakuan minyak kelapa sampai $2 \%$ meningkatkan bobot badan akhir ayam buras super. Bobot badan akhir ayam buras super perlakuan $\mathrm{R}_{3}$ dan $\mathrm{R}_{4}$ lebih tinggi dibandingkan $\mathrm{R}_{0}, \mathrm{R}_{1}$, dan $\mathrm{R}_{2}$. Rasyaf (1994) menyatakan peningkatan imbangan energi ransum mengakibatkan peningkatan sejumlah nutrien yang akhirnya menyebabkan meningkatnya pertumbuhan ayam. Bobot badan akhir ayam buras super dipengaruhi oleh beberapa kandungan yaitu energi dan protein dalam ransum merupakan faktor yang sangat menentukan bobot badan akhir. Rohaeni et al. (2003) dalam peneilitan menjelaskan minyak kelapa sebesar 2,5\% dalam campuran pakan ayam buras menghasilkan konversi pakan sebesar 2,26\%.

\section{Pengaruh Perlakuan Terhadap Bobot Karkas}

Berdasarkan data pada Tabel 4 dapat diketahui rataan bobot karkas ayam buras super yang dihasilkan penelitian ini diperoleh yaitu umur 16 minggu terendah 884,8 g $\left(\mathrm{R}_{0}\right)$ dan tertinggi 1240,8 $\mathrm{g}\left(\mathrm{R}_{3}\right)$. Penelitan ini sejalan dengan penelitan Prayogi (2007) Bahwa tentang penggunaan minyak kelapa dalam ransum, yang melaporkan rata-rata karkas ayam periode finisher yaitu 1,102-1,263 $\mathrm{g}$.

Berdasarkan uji keragaman perlakuan $2 \%$ minyak kelapa dalam ransum dapat meningkat terhadap bobot karkas ayam buras super. Bobot karkas ayam buras super perlakuan $\mathrm{R}_{3}$ dan $\mathrm{R}_{4}$ lebih tinggi dibandingkan $\mathrm{R}_{0}, \mathrm{R}_{1}$, dan $\mathrm{R}_{2}$. Iskandar (2005) dalam penelitian strain ayam dipengaruhi bobot karkas yang mengakibatkan peningkatan bobot badan akhir. Bobot badan akhir mengalami peningkatan akan diikuti oleh bobot karkas, 
sebaliknya bobot badan akhir menurun maka terjadi penurunan bobot karkas.

Peningkatan bobot karkas dalam penelitian ini karena terjadi peningkatan konsumsi pakan. Konsumsi pakan ayam buras super fase grower disusun berdasarkan imbangan protein dan energi metabolis yaitu $17,45 \%$ dan $2829,8 \mathrm{kcal} / \mathrm{kg}$. Penggunaan minyak kelapa sampai $2 \%$ dapat meningkatkan palatabilitas dan mengurangi zat-zat makanan yang hilang. Effendi et al. (2012) dalam penelitian proses metabolisme ayam membutuhkan minyak salah satunya minyak kelapa, karena terdapat vitamin A, D, E, dan K serta provitamin A (karoten) yang larut dalam lemak.

\section{Pengaruh Perlakuan Terhadap Persentase Karkas}

Berdasarkan data pada Tabel 4 dapat diketahui rataan persentase karkas ayam buras super yang dihasilkan penelitian ini diperoleh yaitu umur 16 minggu terendah berkisar $66,95 \%$ pada $\mathrm{R} 4$ dan tertinggi pada R1 yakni 70,21\%. Penelitian ini menghasilkan persentase karkas ayam buras super yang lebih tinggi dihasilkan Trisiwi (2016) dalam penelitian rataan persentase karkas ayam kampung super pada umur 18 minggu berkisar $63,70 \%-65,48 \%$. Hal ini didukung oleh kandungan nutrisi ransum, kondisi lingkungan, umur potong ayam, dan strain ayam dapat memengaruhi persentase karkas yang akan dihasilkan (Suryanto et al., 2009). Menurut Rohaeni et al. (2003) menyatakan bahwa pemberian minyak kelapa sebesar 2,5\% dalam campuran pakan ayam umur 5 minggu menghasilkan persentase karkas sebesar $66,86 \%$.

Berdasarkan uji keragaman perlakuan penggunaan minyak kelapa sampai $2 \%$ dalam penelitian ini menghasilkan respon yang sama pada persentase lemak abdominal ayam buras super. Hasil penelitian ini masih dalam standar persentase karkas ayam yang berkisar $65 \%$ - $75 \%$ dari bobot badan akhir. Bobot badan akhir yang baik menghasilkan bobot karkas sehingga persentase karkas yang dihasilkan baik. Rendahnya persentase karkas tidak akan selalu diikuti dengan tingginya bobot badan akhir dan bobot karkas. Budiansya (2003) dalam penelitian menghasilkan karkas yang baik diikuti oleh pertumbuhan bobot badan akhir ataupun sebaliknya karkas menurun maka bobot bad an akhir menurun.

\section{Pengaruh Perlakuan Terhadap Persentase Lemak Abdominal}

Berdasarkan data pada Tabel 4 dapat diketahui rataan persentase lemak abdominal ayam buras super yang dihasilkan umur 16 minggu terendah pada $\mathrm{R}_{1}$ yakni $0,60 \%$ dan tertinggi pada $\mathrm{R}_{4}$ yakni 1,34\%. Lesson dan Summers (2001) bahwa 
persentase lemak berkisar $1 \%-2 \%$. Hasil penilitian Rohaeni et al. (2003) tentang penggunaan minyak kelapa bahwa, pemberian minyak kelapa 2,5\% dalam campuran ransum ayam buras menghasilkan persentase lemak abdominal sebesar 1,73 .

Berdasarkan uji keragaman perlakuan penggunaan minyak kelapa $0 \%-$ $2 \%$ dalam penelitian ini menghasilkan respon yang sama pada persentase lemak abdominal ayam buras super, karena penggunaan minyak kelapa yang digunakan dalam penelitian ini minyak nabati dan yang disusun energi dalam pakan. Minyak kelapa nabati dapat mengurangi aktifitas enzim lipogenik hati dan menghambat lipogenesis yang mengakibatkan terjadinya penurunan deposit lemak tubuh. Riyanto (2004) dalam penelitian mengemukakan bahwa penurunan lemak tubuh akibat dari aktifitas enzim lipogenesis, lemak yang berasal dari penggunaan minyak nabati.

\section{KESIMPULAN}

Penggunaan minyak kelapa sampai $2 \%$ dalam ransum ayam buras super dapat meningkatkan bobot bad an akhir, dan bobot karkas tetapi menghasilkan persentase karkas dan persentase lemak abdominal yang sama.

\section{UCAPAN TERIMA KASIH}

Terima kasih kepada bidang kerja sama unsrat dan Fakultas Peternakan Universitas Padjadjaran telah melaksanakan kegiatan penelitian tahun 2019. Kepada Rektor Unsrat dan ketua LPPM Unsrat boleh memberikan dana penelitian kerjasama Fapet Unsrat dan Fapet Unpad. Kepada Prof. Dr. Ir. Hj. Tuti Widjastuti, M.S selaku dosen pembimbing eksternal yang sudah banyak membantu dan memberikan bimbing.

\section{DAFTAR PUSTAKA}

Badan Pusat Statistik. 2018. http://www.bps.go.id

Budiansyah, A. 2003. Pengaruh penggunaan silase tepung daging keong mas (pomaceae sp) dalam ransum terhadap pertumbuhan dan karkas ayam broiler. J. Ilmiah ilmu-ilmu peternakan. 6 (4): 227-234.

Direktorat jenderal Perkebunan. 2017. http://www.ditjen.pertanian.go. id

Effendi, A.M., W. Pratjojo, W. Sumarni. 2012. Optimalisasi penggunaan enzim bromelin dari sari bonggol nanas dalam pembuatan minyak kelapa. Indonesia Journal Of Chemical Science 1(1): 1-6

Iskandar, S. 2005. Pertumbuhan dan perkembangan karkas ayam silangan kedu x arab pada dua sistem pemberian pakan. Jurnal 
Ilmu Ternak dan Veteriner 10 (4): 253-259.

Leke, J.R. 2013. Evaluasi nilai nutrisi limbah industri pengolahan ikan cakalang dan implikasinya dalam pakan terhadap penampilan ayam buras. Disertasi. Universitas Bariwijaya Malang.

Lesson dan. Summers. 2001. Nutrition of The Chicken $4^{\text {th }} \mathrm{Ed}$ (Guelph Edition Published by university Books. Guelph Ontario. Canada. ISBN 09695600-5-2.)

Prayogi, H. S. 2007. Pengaruh penggunaan minyak kelapa dalam ransum terhadap konsumsi pakan, peningkatan bobot badan, konversi pakan dan karkas broiler periode finisher. J. Tropical animal Production 6(2): $18-27$

Rasyaf, M. 1994. Makanan ayam broiler. Penerbit Kanisius. Yogyakarta

Rohaeni, E.S., Tri Yuwanta, dan Zuprizal. 2003. Penampilan dan nitrogen ekstreta serta kolestrol darah pada ayam broiler yang mendapat pakan all grain dan non all grain pada level protein yang berbeda. Jurnal Peternakan 27(4): 151-160.

Riyanto, J. dan J.I. Sanyanto. 2004. Penggunaan minyak kelapa dan lemak sapi sebagai sumber energi ransum broiler. Jurnal Indonesia Trop Anim Agric 29:148-155

Sartika, T. 2016. Panen ayam kampung 70 hari. Penebar Swadaya. Jakarta

Steel, R. G. D. dan J.H. Torrie. 1995. Prinsip dan prosedur statistika : suatu pendekatan biometrik. terjemahan B. sumantri. Gramedia pustaka utama. Jakarta.

Suryanto, E., H. Sasongo, Maryam dan R. Santosa. 2009. The effect of type and slaughter age on the perfomances and carcass charactheristic of male arab chicken. J. Indonesia Trop. Anim. Agric. 34 (3): 181-189.

Trisiwi, H. F. 2016. Pengaruh level protein pakan yang berbeda pada masa starter terhadap penampilan ayam kampung super. J. Ilmia Peternakan terpadu Vol. 4(3): 256-262. 